\title{
PREFERENSI SMARTPHONE SEBAGAI ALAT PERJALANAN WISATA DI BALI
}

\author{
I Made Kusuma Negara ${ }^{1}$, Putu Agus Wikanatha Sagita ${ }^{2}$ \\ Email:kusuma.negara@unud.ac.id ${ }^{1}$, aguswika@unud.ac.id ${ }^{2}$ \\ ${ }^{1,2}$ Program Studi Industri Perjalanan Wisata, Fakultas Pariwisata, Universitas Udayana
}

\begin{abstract}
Utilization of tourism information and communication technology has an impact on increasing tourist satisfaction. One of them is the use of smartphones as a travel tool such as booking accommodation, selecting destinations, searching for tourist locations, distance to tourist sites, weather at tourist sites, uploading travel memories, and other travel needs. This study aims to describe the social, economic, demographic variables of tourists in using smartphones as a travel tool in Bali. The basic needs of tourists such as hotels and restaurants are the main needs of tourists in browsing through smartphones. In addition, the conditions at the destination are also a relatively important need for tourists to know through the use of smartphones. Women as domestic tourists dominate the use of smartphones in traveling, most of whom are women who live in metropolitan areas. Meanwhile, for foreign tourists, it looks proportionally distributed based on the country of origin of the tourists. Those who are well-educated dominate the use of smartphones in traveling. The distribution of young and productive ages can also be seen clearly in using smartphones as a travel tool. Even in the case of foreign tourists, the elderly also contributes to the use of smartphones as a travel tool.
\end{abstract}

Abstrak: Pemanfaatan teknologi informasi dan komunikasi pariwisata sangat berdampak meningkatkan kepuasan wisatawan. Salah satunya berupa penggunaan smartphone sebagai alat perjalanan wisata seperti pemesanan akomodasi, pemilihan destinasi, pencarian lokasi wisata, jarak ke lokasi wisata, cuaca di lokasi wisata, mengunggah kenangan perjalanan wisata, serta kebutuhan wisata lainnya. Penelitian ini bertujuan untuk mendeskripsikan variabel sosial, ekonomi, demografi wisatawan dalam menggunakan smartphone sebagai alat perjalanan wisata di Bali. Kebutuhan pokok wisatawan seperti hotel dan restoran menjadi kebutuhan utama wisatawan dalam browsing melalui smartphone. Selain itu, kondisi pada destinasi juga menjadi kebutuhan yang relatif penting untuk diketahui wisatawan melalui penggunaan smartphone. Wanita sebagai wisatawan nusantara mendominasi penggunaan smartphone dalam berwisata yang sebagian besar merupakan wanita yang tinggal di metropolitan. Sedangkan pada wisatawan mancanegara, tampak merata secara proporsional berdasarkan asal negara wisatawan. Mereka yang well-educated mendominasi penggunaan smartphone dalam berwisata. Persebaran pada usia muda dan produktif juga nampak terlihat jelas dalam menggunakan smartphone sebagai alat perjalanan wisata. Bahkan pada kasus wisatawan mancanegara, usia manula juga memberikan kontribusi dalam penggunaan smartphone sebagai alat perjalanan wisata.

Keywords: bali, tourist behaviour, smartphone. 


\section{PENDAHULUAN}

Bali sebagai salah satu destinasi berkelas dunia sangat populer dalam mesin pencari google dalam Travel and Leisure menyebutkan bahwa kata where is Bali menjadi pertanyaan yang paling banyak dicari di tahun 2016. Informasi-informasi tentang keindahan Bali menjadi ulasan serta perbincangan dalam website maupun blog. Dalam beberapa informasi di dunia maya, menyatakan bahwa Bali memiliki pantai yang indah, penduduk yang ramah, serta budaya yang unik, menjadikan Bali sebagai pulau wisata terbaik di dunia verasi Majalah Time and Travel Leisure. Hal ini tidak terlepas dari pemanfaatan teknologi sebagai media pemasaran pariwisata digital. Pesatnya teknologi informasi dan komunikasi pariwisata ini sangat berdampak dalam memberikan kepuasan wisatawan (Setiko et al. 2016). Kehadiran smartphone sebagai bagian dari inovasi teknologi memungkinkan setiap individu selalu terkoneksi satu dengan yang lainnya. Sebagian besar wisatawan ke Bali utamanya kaum muda menggunakan smartphone sebagai alat perjalanan wisata dalam hal pemesanan akomodasi, pemilihan destinasi, pencarian lokasi wisata, jarak ke lokasi wisata, cuaca di lokasi wisata, mengunggah kenangan perjalanan wisata, serta kebutuhan wisata lainnya.

Pergeseran tahapan perjalanan wisata telah berubah seiring kemajuan teknologi semenjak berkembangnya teknologi smartphone (Wang et al., 2011), wisatawan dapat dengan mudah menentukan pilihan sesuai kemampuannya untuk berwisata menyangkut pemilihan hotel, restoran, atraksi wisata secara online. Wisatawan dapat secara spontan mengubah rencana perjalanan wisata akibat kejadian tak terduga yang dialaminya serta berbagi momen berwisata saat di lokasi wisatawan tersebut berada. Smartphone memiliki peran yang mampu memfasilitasi keputusan berwisata dan perjalanan wisata tersebut (Bae, 2010). Bahkan dengan teknologi global positioning system (GPS), menjadikan akses wisata berbasis lokal dapat diakses dengan mudah melalui smartphone (Torun, 2011). Fokus lain yang tidak kalah penting adalah, bagaimana aplikasi perjalanan wisata mampu memberikan layanan yang aman, handal, dan efisien (Wang, 2011) serta dapat memfasilitasi wisatawan dalam perjalanan wisatanya, baik pre trip, on the way, dan after trip (Kristina, 2018).

Penggunaan teknologi smartphone dalam berwisata telah memberikan kemudahan dalam berkomunikasi serta berbagi informasi. Hal ini sangat memberikan pengaruh terhadap perilaku wisatawan dalam menggunakan aplikasi perjalanan wisata (Kristina, 2018). Perilaku wisatawan merupakan suatu keterlibatan wisatawan dalam proses mencari, memilih, menggunakan, serta mengevaluasi untuk memenuhi kebutuhan serta keinginan wisatawan. Aplikasi perjalanan wisata yang tertanam dalam smartphone sangat berperan penting dalam perilaku wisatawan untuk memutuskan suatu perjalanan wisata. Berdasarkan uraian dalam latar belakang sebelumnya, maka yang menjadi tujuan dalam artikel ini adalah untuk mendeskripsikan variabel sosial, ekonomi, demografi wisatawan wisatawan dalam menggunakan smartphone sebagai alat perjalanan wisata di Bali.

\section{METODE}

Sampel lokasi dipilih Ubud, Seminyak, dan Canggu dengan objek penelitian wisatawan sejumlah 100 orang yang dipilih secara purposive. Data yang diambil berupa sosial, ekonomi, demografi wisatawan dalam menggunakan smartphone sebagai alat perjalanan wisata di Bali. Analisis data menggunakan analisis deskriptif kuantitatif. Analisis ini berperan melihat secara deskriptif wisatawan dalam menggunakan smartphone sebagai alat perjalanan wisata di Bali.

\section{HASIL DAN PEMBAHASAN}

Sebanyak 91 persen dengan tujuan untuk berlibur, sisanya sebesar 9 persen memiliki motif untuk bisnis, mengunjungi teman ataupun kerabat, serta motif lainnya. Fakta yang menarik dalam penelitian ini adalah 72 persen dari 50 orang responden telah menggunakan smartphone sebagai alat perjalanan wisata, sedangkan sisanya sebesar 28 persen masih menggunakan media cetak ataupun media konvensional lainnya di dalam berwisata. Dari 72 persen wisatawan yang menggunakan smartphone sebagai alat perjalanan wisata, sebanyak 95 persen wisatawan menggunakannya dalam merencanakan perjalanan wisata, seperti browsing destinasi wisata yang akan dikunjungi, baik gambar maupun informasi 
lainnya yang dibutuhkan. 87 persen wisatawan menggunakan fitur dalam smartphone untuk mencari dan melakukan pemesanan kamar beserta mencari restoran. Sebesar 82 persen dipergunakan untuk peta, ramalan cuaca, serta fitur Global Positioning System (GPS). Kebanyakan atau sebesar 62 persen menggunakan sistem operasi IOS, sedangkan sisanya sebesar 26 persen menggunakan sistem operasi Android maupun Windows Mobile, beserta Blackberry. Hal ini mengindikasikan bahwa sebagian besar wisatawan yang bertujuan untuk berlibur menggunakan sebagian besar fungsi yang tertanam dalam smartphone sebagai sarana untuk perjalanan wisata. Kebutuhan pokok wisatawan seperti hotel dan restoran proteksi covid-19 menjadi kebutuhan utama wisatawan dalam browsing melalui smartphone. Selain itu, kondisi pada destinasi juga menjadi kebutuhan yang relatif penting untuk diketahui wisatawan melalui penggunaan smartphone.

Dilihat dari sumber informasi tentang Bali, sebesar 54 persen wisatawan domestik menggunakan media internet sebagai bahan informasi, 40 persen berasal dari teman atau kerabat, dari travel guide sebesar 5 persen, sisanya sebesar 1 persen memperoleh informasi melalui airlines, tourist office, travel bureaus, serta lainnya. Sedangkan pada wisatawan mancanegara, sebesar 46 persen wisatawan mancanegara mengemukakan bahwa informasi tentang Bali diperoleh dari internet. Dari teman atau kerabat sebesar 32 persen, serta dari travel guide sebesar 9 persen. Sedangkan sisanya sebesar 3 persen ada yang memperoleh informasi dari airlines, tourist office, travel bureaus, embassy, serta lainnya. Hal ini mengindikasikan bahwa sebagian besar wisatawan menggunakan smartphone, harus bertautan dengan sarana internet. Kedua hal ini menjadi kebutuhan yang saling tidak lepas antara smartphone dengan internet. Tanpa koneksi internet, maka smartphone tidak akan memiliki fungsi yang optimal dalam penggunaanya sebagai alat perjalanan wisata.

Berdasarkan jenis kelamin wisatawan domestik, 53 persen merupakan wanita, dan sisanya sebesar 47 persen merupakan pria. Sedangkan wisatawan mancanegara didominasi oleh pria sebesar 55 persen, dan sisanya sebesar 45 persen merupakan wanita. Wisatawan domestik tersebut, kebanyakan berasal dari Provinsi DKI Jakarta sebesar 72 persen, Jawa Timur sebesar 12 persen, Jawa Tengah sebesar 10 persen, serta Jawa Barat sebesar 6 persen. Sedangkan dari wisatawan mancanegara terdiri dari wisatawan berkebangsaan Jerman sebesar 28 persen, Belgia sebesar 1 persen, Kanada sebesar 3 persen, Inggris sebesar 7 persen, Finlandia sebesar 1 persen, Prancis sebesar 8 persen, Rusia sebesar 7 persen, Belanda sebesar 16 persen, Cina sebesar 6 persen, Italia sebesar 3 persen, Jepang sebesar 1 persen, Malaysia sebesar 7 persen, Norwegia sebesar 1 persen, Selandia Baru sebesar 2 persen, Spanyol sebesar 1 persen, Swedia sebesar 3 persen, Swiss sebesar 2 persen, serta Amerika sebesar 5 persen. Wanita mendominasi penggunaan smartphone dalam berwisata yang sebagian besar merupakan wanita yang tinggal di kota metropolitan. Kondisi ini nampak pada wisatawan nusantara. Sedangkan pada wisatawan mancanegara, tampak merata secara proporsional berdasarkan asal negara wisatawan.

Dilihat dari segi usia, wisatawan domestik dalam penelitian ini memiliki usia terendah 18 tahun dan tertinggi 56 tahun. Mereka terdiri dari usia 18-22 sebesar 25 persen, usia 23-27 sebesar 28 persen, usia 2832 sebesar 19 persen, usia 33-37 sebesar 5 persen, usia 38-42 sebesar 9 persen, serta usia 42 tahun keatas sampai dengan 56 tahun sebesar 14 persen. Sedangkan wisatawan mancanegara memiliki usia terendah 18 tahun dan tertinggi 64 tahun. Adapun komposisinya, mereka terdiri dari usia 18-22 sebesar 28 persen, usia 23-27 sebesar 25 persen, usia 2832 sebesar 22 persen, usia 33-37 sebesar 11 persen, usia 38-42 sebesar 10 persen, serta usia 42 tahun keatas sampai dengan 64 tahun sebesar 4 persen. Tingkat pendidikan wisatawan domestik terdiri dari SMA sebesar 21 persen serta sisanya sebesar 79 persen telah mengenyam pendidikan Universitas. Demikian pula wisatawan mancanegara didominasi latar belakang pendidikan Universitas sebesar 57 persen, 23 persen memiliki latar belakang pendidikan Diploma, sedangkan sisnya sebesar 20 persen memiliki latar belakang pendidikan SMA. Mereka yang well-educated mendominasi penggunaan smartphone dalam berwisata. Persebaran pada usia muda dan produktif juga nampak terlihat jelas dalam menggunakan smartphone sebagai alat perjalanan wisata. Pada kasus wisatawan mancanegara, usia manula juga memberikan 
kontribusi dalam penggunaan smartphone sebagai alat perjalanan wisata. Penggunaannya juga telah merambah pada proteksi covid-19 yang sedang melanda dunia semenjak akhir 2019. Peranan smartphone ini menjadi sangat strategis pada penggunaan aplikasi perlindungan dan tracing covid-19.

Penggunaan smartphone dalam perjalanan wisata yang dominan telah menguah cara perjalanan wisatawan menjadi lebih menarik dan atraktif. Seperti yang dikemukakan oleh Wang et al. (2014) penggunaan smartphone dalam pariwisata merupakan kombinasi kompleks dari berbagai fungsi dan layanan informasi yang dibutuhkan wisatawan untuk berkomunikasi seperti hiburan guna memudahkan kebutuhan wisatawan saat berlibur dan mencari informasi berkaitan dengan pariwisata. Banyak pengembang aplikasi perjalanan yang tersedia di internet seperti tripadvisor, agoda booking.com, traveloka telah memposisikan smartphone seagai alat perjalanan.

Temuan ini sejalan dengan Wang et al. (2014), bahwa motivasi intrinsik dan ekstrinsik adalah faktor paling mendasar yang mendorong wisatawan untuk menggunakan smartphone dalam memenuhi kebutuhan perjalanan wisatanya. Tanpa adanya motivasi ini, wisatawan tidak akan memerlukan smartphone sebagai alat perjalanan wisata. Kepercayaan wisatawan akan informasi yang tersedia secara online juga menjadi faktor pendorong wisatawan untuk mempercayakan alat ini sebagai online guide yang menuntun mereka menginap, menyajikan informasi apa saja ketika menuju destinasi termasuk kondisi lalu lintas serta cuaca yang akan mereka hadapi selama melakukan perjalanan di Bali.

Gretzel dalam Wang et al (2014) menyoroti penggunaan smartphone yang telah mengubah pengalaman wisatawan sehubungan dengan penggunaan informasi pariwisata. Pertama, dengan tersedianya informasi secara online, wisatawan dapat dengan mudah menentukan pilihan sesuai kemampuan waktu serta ekonomi untuk memilih hotel, restoran, maupun penunjuk arah. Kedua, dalam kondisi yang tidak terduga, wisatawan dapat mengubah keputusan rencana perjalanan yang awalnya direncanakan ke rencana cadangan. Smartphone dapat membantu menuntaskan kejadian tidak terduga ini, karena informasi dapat diakses wisatawan sangat realtime dalam perjalanan wisata. Menurut Wang et al.
(2014), dalam kondisi ini aktivitas perjalanan wisata menjadi lebih spontan atau menghasilkan perjalanan wisata yang tidak direncanakan (unplanned). Terakhir, fitur smartphone telah dibekali dalam menyimpan momen dan terunggah secara online. Hal ini menempatkan smartphone menjadi alat dokumentasi berbagai pengalaman menarik wisatawan. Terlebih telah terkonekasi dengan media sosial, terdapat umpan balik positif menjadikan penghargaan sosial wisatawan. Jika dibandingkan dengan era pra smartphone, pengalaman berbagi momen ketika berwisata akan terjadi setelah wisatawan tiba di negara asalnya.

\section{SIMPULAN}

Kebutuhan pokok wisatawan seperti hotel dan restoran serta proteksi covid-19 menjadi kebutuhan utama wisatawan dalam browsing melalui smartphone, juga nampak telusuran kondisi pada destinasi menjadi kebutuhan penting wisatawan melalui penggunaan smartphone. Wisatawan nusantara wanita mendominasi penggunaan smartphone dalam berwisata yang sebagian besar merupakan wanita yang tinggal di metropolitan. Sedangkan pada wisatawan mancanegara, tampak merata secara proporsional berdasarkan asal negara wisatawan. Mereka yang berpendidikan tinggi mendominasi penggunaan smartphone dalam berwisata. Persebaran pada usia muda dan produktif juga nampak terlihat jelas dalam menggunakan smartphone sebagai alat perjalanan wisata. Bahkan pada kasus wisatawan mancanegara, usia manula juga memberikan kontribusi dalam penggunaan smartphone sebagai alat perjalanan wisata.

\section{Ucapan Terima Kasih}

Penulis mengucapkan terima kasih yang setinggi-tingginya kepada: Rektor Universitas Udayana, Ketua LPPM Universitas Udayana, Dekan Fakultas Pariwisata Universitas Udayana, berserta Ketua Program Studi Sarjana Industri Perjalanan Wisata Universitas Udayana yang telah memberikan bantuan moril dan materiil guna terselenggaranya penelitian Hibah Unggulan Program Studi tahun 2021. 


\section{Kepustakaan}

Bae, K.Y., 2010. Self-Tour Service Technology based on a Smartphone.Journal of Intelligence and Information Systems, 16(4), pp.147-157.

Dickinson, J.E., Ghali, K., Cherrett, T., Speed, C., Davies, N. and Norgate, S., 2014. Tourism and the smartphone app: Capabilities, emerging practice and scope in the travel domain. Current Issues in Tourism, 17(1), pp.84-101.

Kristiana, Y., 2018. Aplikasi Perjalanan dan Perilaku Wisatawan. Jurnal Pariwisata Pesona, 3(1), pp.1-18.

Setiko, R.K. and Sani, F.E., 2016. Peranan Akurasi Sistem Komputer Hotel di Front Office Department Dalam Meningkatkan Kepuasan Tamu di The Balava Hotel Malang. Jurnal Pariwisata, pp.22-38.

Torun, D., 2011. Usage of Smartphone Applications in Tourism.

Wang, D., Park, S. and Fesenmaier, D., 2011. An examination of information services and smartphone applications. 